\title{
電筷檢曆におけるSPGの計测
}

淵田隆阴 ${ }^{* *}$

(偝机27年 9 月 5 日受理)

\section{Direct Measurements of SPG in Electrical Logging}

by Takato FUCHIDA

It has been frequently experienced at the Tokyo Natural Gas Field that SP curves are distrurbed by the stray current from the electric cars or others.

The writer has advanced the direct measurements of SPG (Self Potential Gradient) instead of SP and showed that the reliable SPG curve is better than the unreliable SP curve. Because the SPG curve is not disturbed by the stray current.

\section{1. 緒言}

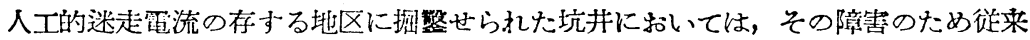
のSP計測方式によつては，倠賴し得べき SP 現象の把握が困難なことが多い。第者 は，そ狄に対する 1 つ解決策として，SP そのもののかわりに，その傾度を直接記 録する方式を思い立ち，2，3，の実験炎重ねたので，その結果をこけに報告する。

\section{2. 從来の SP 計測}

坑井内の SP 計測は Schlumberger の着想以来今日に至 るまで, 测定原理的には少しも变つていない。(第1困) そもそも，いわゆる SP 現象の如き定労電界の笑態を捉之 るには，とにかく電位分布状態を知りさえすがばよいので あるが，かつる電界の計測方式としては，任意の圆定点に 比べての各点の電位差の变化を追跡するという方式が最も 基本的な行き方であるし，しかも，SP の実態が，か小る 計測方式による結果の直接裁現, いわゆる SP 曲線の形式 で示されてある方が，地層の性格を判読するに最す好都合 なようなものであるからであろうと思われる。

第 1 図

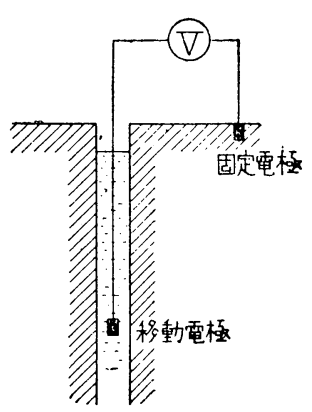




\section{SP 計測の困難な場合}

ところで, 従来の方式によつては真実の SP 現象把暒し，難い場合がある。実は筆

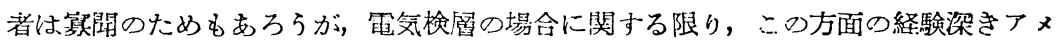
リカの情報にもかかる報告を見受けなからたことよりする慢然たる先、大観念により， 自ら経験するまでは気付かなからたのである。

等者は昭和 26 年 9 月，昭和天然ガス (怢)，川崎試堀 R 1 号井に抋いて笑験の機会 を得たが，その際得られた SP 曲線は異常であることに気付いた。そこで繰返し測

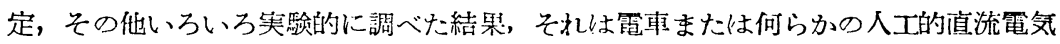
施設よりの非定常の迷走地電流があつて，そ礼が本来の SP に重畳し (8 5 参照)，

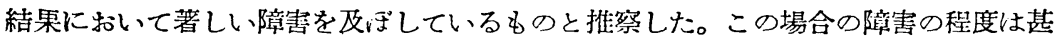
しくて３回の繰返し測定結果より相似性を見出すことも容易でないくらいだつた

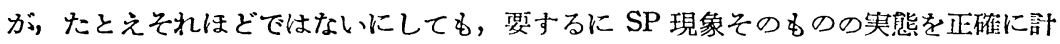
測できないことは，電気検層としては甚だ望ましくないことである。しかも，東京ガ ス田の如く都市地区に開発される場合は，今後しばしば遭遇の可能性のある問題で， この際この対策を研究しておくことは誡に意義あることと考えられる。

次節以下に颃いて記述する SPG 記録方式は，上述の趣旨に沿つて等者が提唱しょ らとする最も簡便にして，しかも一応正しく SP 現象を把握できる解決策の 1 つであ ると信ずる。

\section{S P Gの蓸味}

SPGなる記号は SP (Self Potential) そのものと区別するために篗者か倠に探用し ているものであつて, SP の傾度 (Self Potential Gradient) の意味である。したが つて, SPG は数学的には SP の微分である。 第 2 図 すなわち， $\mathrm{x}$ を樑度とし， SP 曲線が $\mathrm{f}(\mathrm{x})$ に て翌わされるるのとすれい゙， SPG 曲線は $\mathrm{df} / \mathrm{dx}$ にて垗わされるような関保にある。例を示せば 第 2 四の如くである。

さて，両曲線の関係は上述の如くであるので

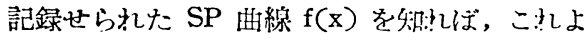
り微分計算により SPG 明線 $\mathrm{df} / \mathrm{dx}$ が得ら!ไる

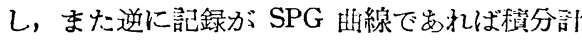
算によつて SP 曲線が得ら札道理である。乙

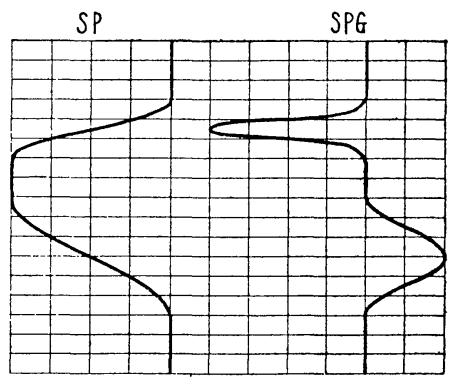

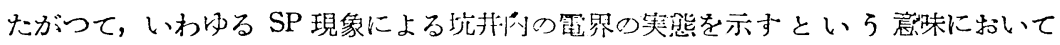

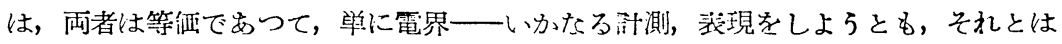
無関係に存する坑找内の自然の资—の琵晲形式老罢にするにすぎない。*もつとも

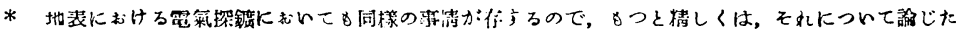
次の㻆交を照せられれい。

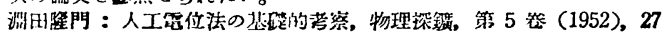


これは純電気学的意味に和いてが岁つて，結果判溒に際しての利便の問題は別であ。

\section{S P G 記錄方式}

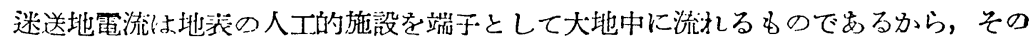

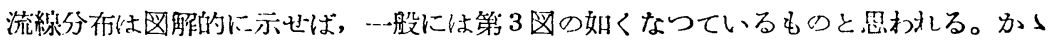
る流緗分布のとき， $\mathrm{P}_{1}, \mathrm{P}_{2}, \mathrm{P}^{\prime} \oslash 3$ 点をよ 第 3 図 ぎる等西位而はそれでれ $\mathrm{S}_{1}, \mathrm{~S}_{2}, \mathrm{~S}^{\prime}$ の如くな るが, 今, 间隔 $\mathrm{P}_{1}$ - $\mathrm{P}_{2}$ は $\mathrm{P}_{1}-\mathrm{P}^{\prime}$ に比べて遥 出に小さいものとするいば, $\mathrm{S}_{1}-\mathrm{S}_{2}$ は $\mathrm{S}_{1}-\mathrm{S}^{\prime}$ に比べて遥かに小さいものとなる。かりに前 者が 1：100 の製合とす:゙ば，大体において 後者もその程度となる。そこで $\mathrm{S}_{1}$ - $\mathrm{S}^{\prime}$ 闍の

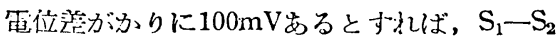
間のそ?しは $1 \mathrm{mV}$ あこととなる。故に $\mathrm{S}_{1}-\mathrm{S}^{\prime}$

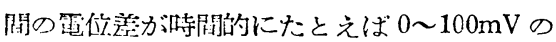

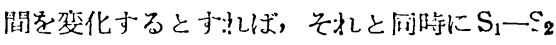
閆に見られる翌化は 0 〜 $1 \mathrm{mV}$ ということにな 子。

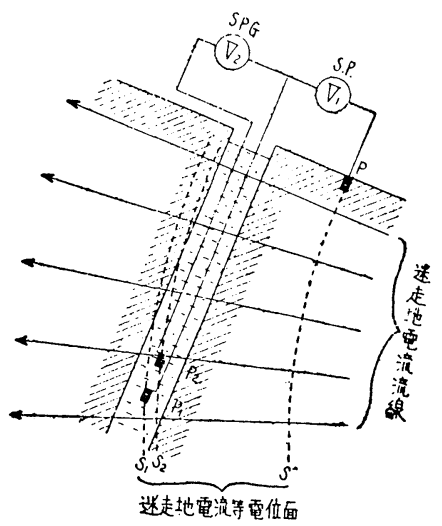

彷茳の SP 記録方式は上図についていえば， $\mathrm{P}^{\prime}$ と $\mathrm{P}_{1}$ を测定電極とし， $\mathrm{P}^{\prime}$ は地上

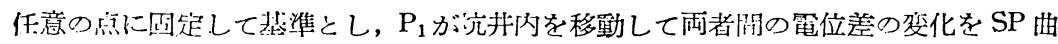

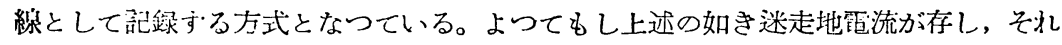
による $\mathrm{S}_{1}$ 一 $\mathrm{S}^{\prime}$ 間の電位美がいわゆる SP 現象に基く坑井内の局部電位变化の程度に 比べて無視し得る程度に小さくなくて，しかも時閏的に变化するときは，記録せられ

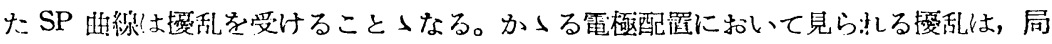

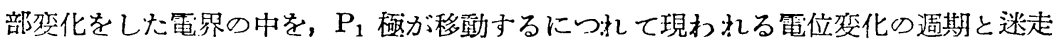
地電流のもつ调期—こっで週期とは時間的变化の緩急の度合を示す意味で使用する 一とが瑟しく違つていない限り，本質的に分離観测できない性格のものである。

ところで, $\mathrm{P}^{\prime}$ の代りに $\mathrm{P}_{1}$ と一定の小間隔，たとえば $1 \mathrm{~m}$ を保つて移野する電極 $\mathrm{P}_{2}$ を採用し， $\mathrm{P}_{2}-\mathrm{P}_{1}$ 間の電位差を測定することにすれば，迷走地電流による電位差 $\left(\mathrm{S}_{1}\right.$ 一 $\mathrm{S}_{2}$ 間) は上述の如く桯めて小さいのに反し, SP 現象による属部電界の電位差 は正味のま小感知されるので，結果においては迷走地電流による障害をほこんど受け ることなく, 坑投内の局部電界の実態を $\mathrm{P}_{2}-\mathrm{P}_{1}$ 間の電位差とい5 形において計测し 得ることとなる。

測定中 $\mathrm{P}_{2}-\mathrm{P}_{1}$ 䦌隔を $1 \mathrm{~m}$ に保てば, 両電極間に感知される電位差は, 坑井に治つ て $1 \mathrm{~m}$ 当りの電位变化の割合，才なわち $\mathrm{SP}$ の傾度といらことになるわけだから， けつきよくSP の傾度の直接計測方式を探用すれば迷走地電流の障害を受けることな く, SP 現象による局部電界のみを把握し得ること〉なる。 


\section{6. 実驗}

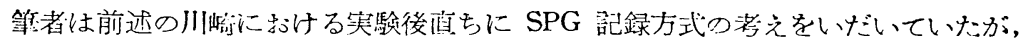

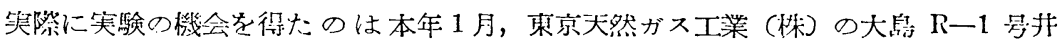

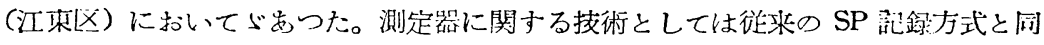
じでよいわけで，たげ結線を第 3 四における $\mathrm{V}_{1}$ 測定回路の代りに $\mathrm{V}_{2}$ 測定 第 4 図 回路を使用才ればよい。電線や電極を增設する必要はない。といらのは，笋 者が使用している䇝極忙第 4 目の如きるので， $\mathrm{P}_{1}$ を地上の $\mathrm{P}^{\prime}$ と組合せて PS をC一 $\mathrm{P}_{1}, \mathrm{C}-\mathrm{P}_{2}$ によつてそれぞれ笛極間隔 $30 \mathrm{~cm}, 90 \mathrm{~cm}$ の 2 極方式 見掛比抵抗を棓録しているので，㨁ちに $\mathrm{P}_{1}$ と $\mathrm{P}_{2}$ の組合せによつて $60 \mathrm{~cm}$ 当りの SPG を测定できるからである。

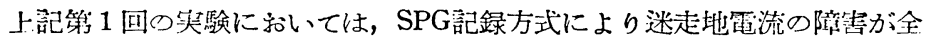
く除冯ることが観察できたし，かつ記録曲線は于想どおり SPG らしき形 のものを得ることができた。たら゙,全く予期しないことではなかつたが， $\mathrm{P}_{1}$,

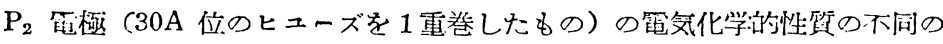
ため，坑井内泥水との䦬に生ずる笚極電位差が等しくないためと思わ虬る $10 \mathrm{mV}$ 位の基線のズレがみられ九たしかしこのズレは䀒線の形に笑係ない ばかりでなく，必要とあらば曲線全体の観察により容易に推測できるもので 大して重要な茂障となるるのではないと思われた。

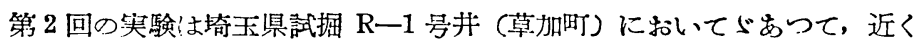

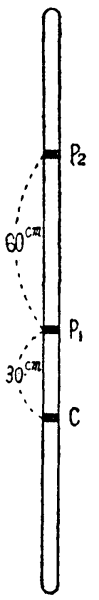
を通る電本の影響がみられたので笑施したのである。そのときのSPG 胉線は，比抵 抗曲線と対比しながら観察すると，若干の位置のブレはあるが，むしろ SP 曲線らし い部分もまり，正しく SPGを記録していないのではないかの疑念を生じた。しかし

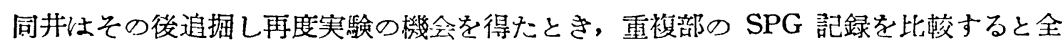
く同じであるので，そのことより推察してたまたまの測定器の故障などによるのでは なくて，同井の SPG がそらいらものであると一応結諭した。

しかしその後念のため迷走地電流の障害のない所で, 同じ測定器によつて SP と SPG とを同時記録して比較することを活十画し，相生工業（株）第 581 号井 (千浆桨 八程村）においてこれを実施する機会を得た。この笑駼結牀によつて, SPG 曲縓は一 応正しくSP 出線の倾度に相当していることがはつきりと涩めら!?した。そのときの結 果の 1 部を第 5 四* に示す。四中 $\mathrm{R}$ 幽總は $\mathrm{C}-\mathrm{P}_{1}$ の組合せによるもの，また下半分 は記録紙の送りの具合を普通のと括り $2 \mathrm{~mm} / \mathrm{m}$ にした場合，上半分は $6 \mathrm{~mm} / \mathrm{m}$ にし て曲線の变化を明瞭に記録させた㘿合を示してある。

筆者が SPG 記録方式研究の目的をもつておこなつた実験の概要は，以上で尽して いるのであるが，参考のため実跧条件の異る場合の例をむ第 6 困に示しておく。これ

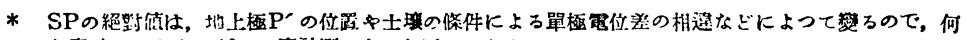

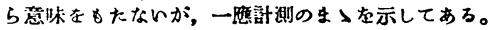


第 5 図

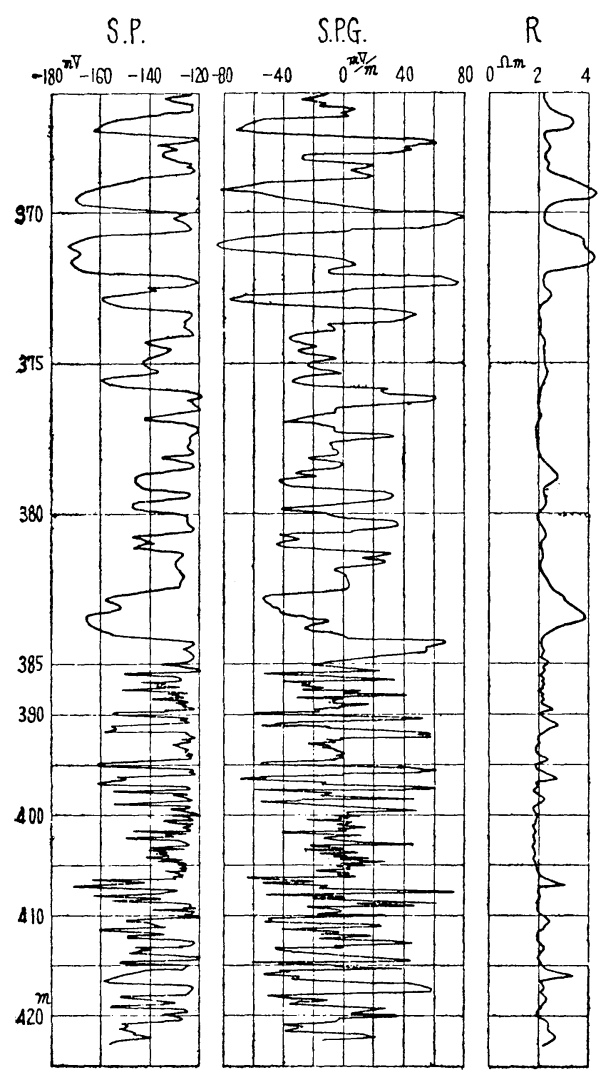

第 6 図

S.P.

S.P.G.
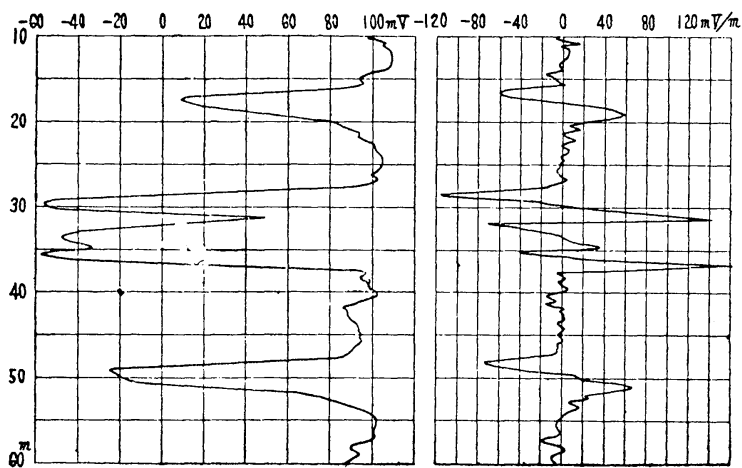

は勧者か辢潟地区天然ガス井の鋼

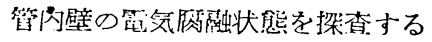
目的をもつて扣こなつた 1 例であ

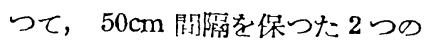
電植老移勒電極とし， 1 極と地上 極とによつて SPを， 2 極によつ てSPG この䭪合知りたいものは SPGそのものではなくて，そ扎 比例する電流密度であつたつを同 時䛉録せしめたるのである。この 際抯述の実㩆と特に罢る条件は電

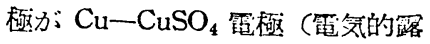
出部の長さ約 $20 \mathrm{~mm}$ ) であること と，比抵抗測定をおこなわないの で純然たる直流汁測に終始してい ることである。両助線が无に合理 的関保になつていることは改めて 説明する必要もないことだが，た ら゙電極が非分極性だけに，金属電 極によつて前に経験したような基 線のブレはみられななにとは，特 に附䨐して扣きたいことである。

\section{SPGの積分について}

過去に控いて SP 曲綩の判読に 習熟した多くの拔術者 にとつては, SPG ょり SP の方がより便利に 感ぜられるにとは容易 に察することができ る。ところで 4 におい て述べたよらに，SPG を积分寸礼ばSP が得 られる道理である。し かし，笑際の記録曲線 がたとえば第 5 四の如 く変化が急で頻繁な場 
に，その計算の正確を期することは容易なことではない。

そこで，こ狄は，SPG記録を余儀なくされるる頿度と上述の要望の程度とによつて，

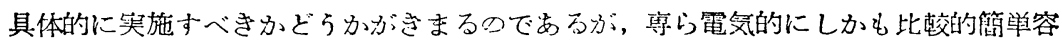
易に実現の可能性ありと思わ礼る方法が考えら扎るので，一応原理だけを紹介してお $<$ 。

それはは電㥛としては SPG 方式の $\mathrm{P}_{1}-\mathrm{P}_{2}$ の組含せによつて迷走地電流の影響を避 け，ガバに特殊のものを使つてこれによつて所要の䅡分を就こなわせるのである。 原理は極めて簡単である。すなわちガルバの強制振動の一般運動方程式は

$$
\theta^{\prime \prime}+2 \varepsilon \theta^{\prime}+n^{2} \theta=\phi(t)
$$

で表わされるが，この際 $\varepsilon$ が極めて大きく $\mathrm{n}$ が極めて小さいときは

$$
2 \varepsilon \theta^{\prime} \fallingdotseq \phi(\mathrm{t})
$$

となるので

\section{$\theta \infty \int \phi(t) d t$}

となつて,ガルバのフレの角 $\theta$ は強制力となる電流の䖽分値に比例することななる。 そこで電流がSPGに比例しているときは， $\theta$ はSPに比例することななるのである。

\section{8. 結 言}

この報告においては，人工的迷走地霆流が存してそれが障害となつて，SP の直接 記録が泪難な場合にも，SPG 直接記録方式を採ることによつて坑井内の局部電界を 正しく把握し得る道理を説明しかつそれが実験的に容易に于想どおりに笑現し得る ことを示している。

箓者は，SP 万式が利蜼な場合に雐賴するに足らないSP 曲線を記録するよりは， SPG 方式によつて霹賴するに足るSPG 曲線を得た方がよい，という程度の考えをむ つてこれを提唱しているものであるが，一方一般の判読技術者にとつては SP 明緗の 方がつごらがよいとも考えられるので，さらに1步を進めて，たとえば前節に述べた 如き要領により，SPG 電極により SP 曲線を記録させる方式の笑現が望ましいと考 える。

電気検周に関する实験の機会は随意には選べない。この研究は, 実験の顺序に, 昭 和天然ガス (株) ・東宗天然ガス工業 (株) ・堬玉罢庁・相生工業 (株) と籢井に関 係せられたる大多喜天然ガス（株）・湘南ドリリング（株）の深い御理解と御抵話と によつて，初めておこならことができたものである。こけに厚くお礼申上げる。なお 算者の笑験助手として島津孝・石原義雄雨君に缜らところ極めて大きく，また製図は 神津敬子壤を暊した。この機会に深く感謝の塣を装する。

最後に，本研究は昭和26年度の文部省科学侀究費の援助によるところ多く、こなに 謝意を裴する。 